\title{
Demonstrating Usefulness of Real-Time Monitoring at Streambank Wells Coupled with Active Streamgages-Pilot Studies in Wyoming, Montana, and Mississippi
}

\section{Introduction}

Groundwater and surface water in many cases are considered separate resources, but there is growing recognition of a need to treat them as a single resource (Winter and others, 1998; Alley and others, 1999). For example, groundwater inflow during low streamflow is vitally important to the health of a stream for many reasons, including buffering temperature, providing good quality water to the stream, and maintaining flow for aquatic organisms. The U.S. Geological Survey (USGS) has measured stream stage and flow at thousands of locations since 1889 (Gohn, 2004) and has the ability to distribute the information to the public within hours of collection (Nielsen and Norris, 2007; Cunningham, 2001), but collecting shallow groundwater data at co-located measuring sites is a new concept

Recently developed techniques using heat as a tracer to quantify groundwater and surface-water exchanges (Stonestrom and Constantz, 2004) have shown the value of coupling these resources to increase the understanding of the water resources of an area. In 2009, the USGS Office of Groundwater began a pilot study to examine the feasibility and utility of widespread use of real-time groundwater monitoring at streambank wells coupled with real-time surface-water monitoring at active streamgages to assist in understanding the exchange of groundwater and surface water in a cost effective manner.

\section{Approach}

All sites selected for this pilot study have year-long operation and are located in areas expected to have regional groundwater flow to or from the stream. Seven sites were selected to test the concept over a range of stream settingsfrom a small stream in mountainous Wyoming, to a midsized intermontane river in Montana, to a large river in the Mississippi Delta. Although the variety of site types dictated some variations in site-specific equipment, all observation wells were similarly constructed, with well installation 15 to 30 feet from the edge of the streambank and completed to a depth of 10 feet below the estimated lowest level of the water table. As such, the well provides an indication of the hydraulic head at a specific depth beneath the streambed and does not necessarily indicate the elevation of the water table adjacent to the stream.

The streambank observation wells were instrumented to measure water level and temperature at the bottom of the well at 15-minute intervals using a pressure transducer and temperature sensor. Stream temperature was measured using a network thermistor placed in the stream (fig. 1). All data were collected by using USGS protocols (Cunningham and Schalk, 2011; Sauer and Turnipseed, 2010; Wagner and others, 2006). The groundwater data and stream temperature data were collected and transmitted to the streamgage data recorder (fig. 1), which were then transmitted by way of satellite to a receiving station. Six of the sites were hard-wired to allow

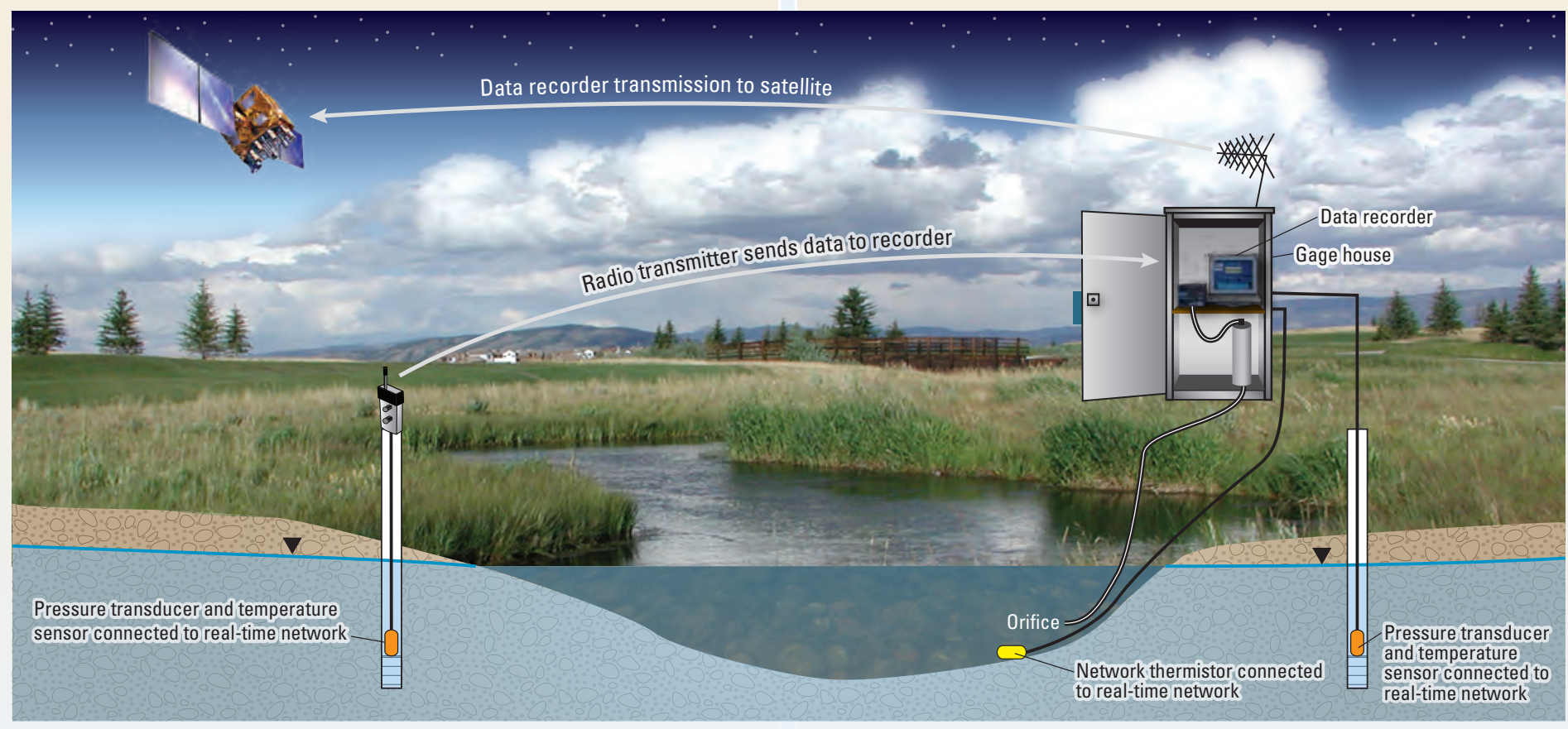

Figure 1. Design of generic observation well installation at streamgage featuring hard-wired recorder and radio-transmitted data for surface water and groundwater. 
for data transmission from the observation well to the data recorder. The exception was the Big Sunflower River at Sunflower in Mississippi, where the desired location for an observation well was across the stream from the data recorder in the streamgage. Because the distance between the observation well and streamgage was greater than available cable length, radio transmissions were used to transmit data from the well to the data recorder (fig. 1). Finally, all sites were surveyed to accurately compare elevations with each streamgage datum.

Transmittal of the groundwater data along with the stream data to a satellite and then to the Web for viewing in real time was an important component of the pilot study (U.S. Geological Survey, 2011). Real-time transmission of the data allows timecritical viewing and decisionmaking in response to dynamic changes in the near-stream environment, such as reversals in flow direction between groundwater and the stream.

Most site visits to manually measure groundwater, to verify measurements with the data recorder, and to adjust the offset in the measured and recorded data (if necessary) coincided with the regularly scheduled visit for the streamgage. USGS personnel responsible for data collection at specific streamgages were responsible for the additional groundwater level and temperature measurements, and found the time commitment for the additional measurements to be small compared with the total time required to service the streamgage.

\section{Pilot Study Site-Specific Observations}

Coupled groundwater and surface-water data obtained for the sites were used in a different manner at each site to expand the understanding of the interaction. A short summary of how collected data were used for four sites in the pilot study are shown in figures 2 and 3. Detailed graphic data and results are presented for three focus sites: Flat Creek below Cache Creek, near Jackson, Wyoming (figs. 4-7), Big Sunflower River at Clarksdale, Mississippi (figs. 8-11), and Big Hole River near Melrose, Montana (figs. 12-15).

- During June 2011, the Wind River near Kinnear, Wyoming (streamgage 06227600; fig. 2), had near-record flows, resulting in flooding and damage to the streamflow stage instrumentation. This damage resulted in missing data during the highflow period. Because the groundwater level in the observation well closely followed the stream stage, the groundwater-level data were used to provide a better estimate of the peak streamflow at the site.

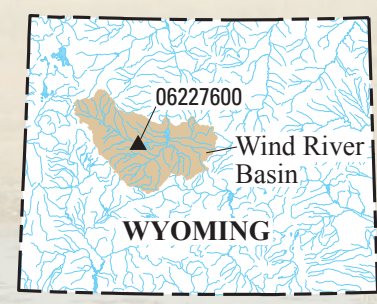

Figure 2. Location of U.S. Geological Survey streamgage at Wind River near Kinnear, Wyoming.
- Streamflow in the Big Sunflower River (streamgage 07288500; fig. 3) has been severely altered by loss of base flow owing to declining water levels in the underlying alluvial aquifer. Historically a predominantly gaining stream, the Big Sunflower River is now a predominantly losing stream. Flow augmentation is now required in the central reaches which flow over a cone of depression that has formed in the alluvial aquifer (Barlow and Clark, 2011). The addition of three coupled streambank observation wells at streamgages 07288500,07288700 , and 323045090484300 along the Big Sunflower River has allowed for an increased understanding of how groundwater/surface-water exchange varies temporally and longitudinally. These new data have provided water managers with valuable information that can be used to better manage and maintain streamflow.

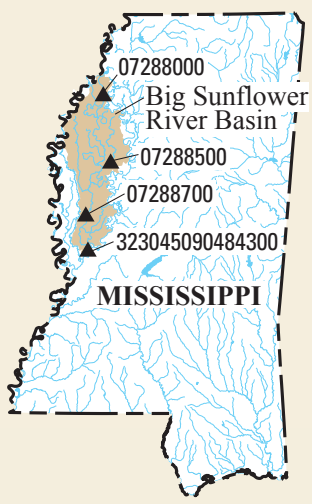

Figure 3. Location of U.S. Geological Survey streamgages on the Big Sunflower River, Mississippi.
Groundwater level is measured periodically to verify readings from pressure transducer in observation well. Photograph shows measurement taken at Wind River

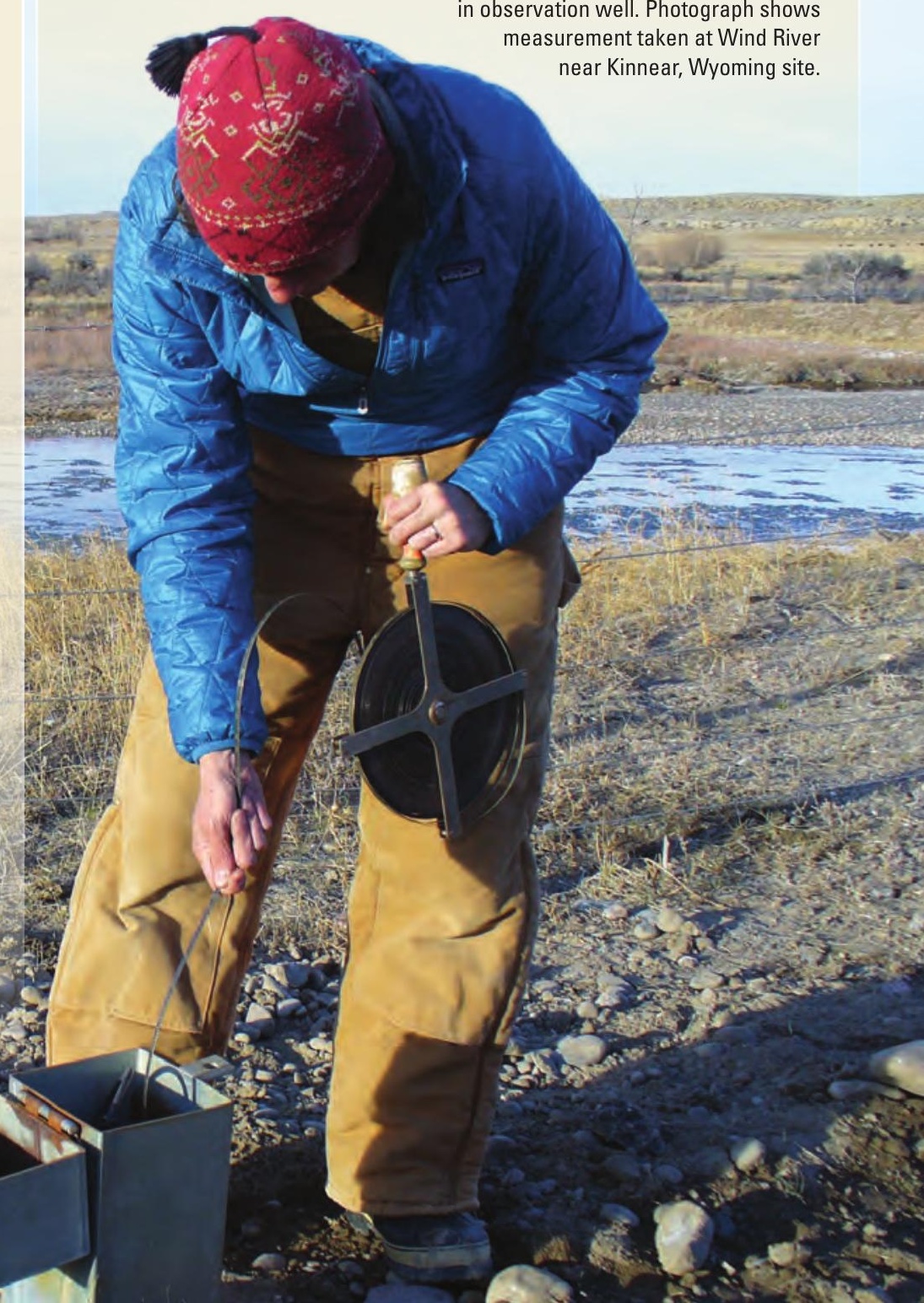




\section{Flat Creek below Cache Creek, near Jackson, Wyoming (streamgage 13018350)}

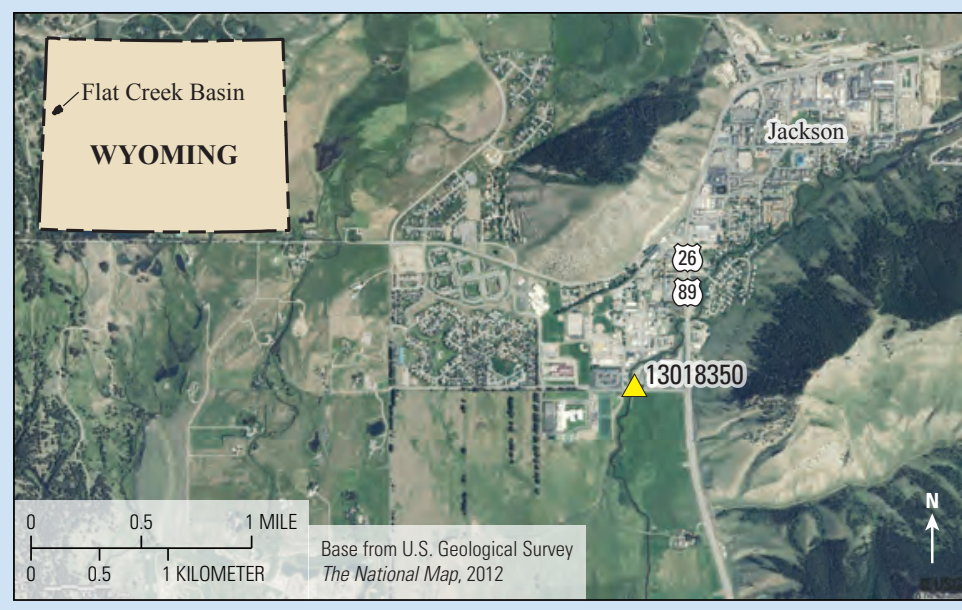

Figure 4. Location of U.S. Geological Survey streamgage 13018350 at Flat Creek below Cache Creek, near Jackson, Wyoming.

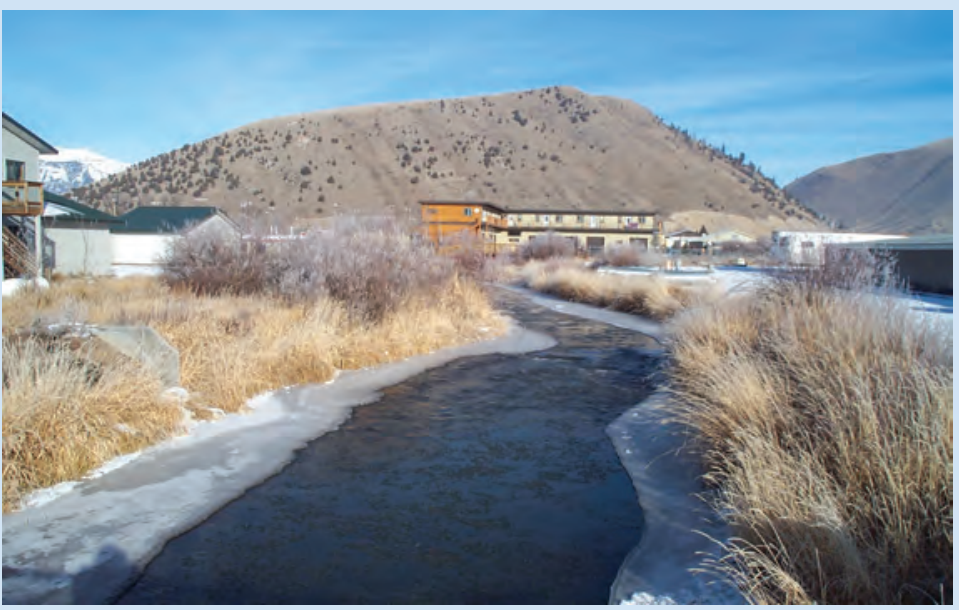

Figure 5. View looking upstream on Flat Creek below Cache Creek, near Jackson, Wyoming, on November 21, 2000.
Setting.-Flat Creek (figs. 4 and 5) originates in the mountains of western Wyoming. After the creek leaves the mountains, it flows through a large grassland and meadow. The observation well is 15 feet from Flat Creek at the USGS streamgage. The well is completed 17.6 feet below the streambed in sand and gravel.

Flat Creek below Cache Creek near Jackson, Wyoming.-The drainage area at the streamgage is 129 square miles of primarily mountainous terrain with a mean annual streamflow of 78 cubic feet per second (water years 1989-2011; U.S. Geological Survey, 2011).

Data.-During most of the winter, the groundwater level does not closely follow the creek stage. Flat Creek commonly freezes during the winter, causing ice dams along the river, including the streamgage location, noted by the blue circles on figures 6 and 7 . The extended period of freezing temperatures in early December caused an increase in the amount of water backed up by the ice dam. Around December 9, 2011, this higher stage and subsequent infiltration of surface water into the ground is indicated by the rise in the local groundwater level (fig. 6). The infiltration of near-freezing water also can be detected in groundwater temperature with a noticeable decline starting on December 12. Residential basements began flooding near the creek with rising groundwater levels. On December 13, a nearby thaw-well (a deep well that pumps relatively warm groundwater) was turned on, pumping warmer water into the creek to melt ice and allow the creek to flow freely again, decreasing water infiltrating into groundwater (Sean O'Malley, Town of Jackson, personal commun., 2012).

Practical applications. - This is an example of how real-time groundwater data can be used by water managers to be able to mitigate the effects of rising groundwater. Once this relation between surface water and groundwater is understood, a USGS service called WaterAlert (U.S. Geological Survey, 2012) can be used. The USGS WaterAlert service allows individuals to be notified when water data reach user-specified conditions. This will allow water managers to be notified when stream stage or groundwater levels are nearing critical elevations, and data can be viewed to potentially take action before a problem occurs and without needing a site visit.

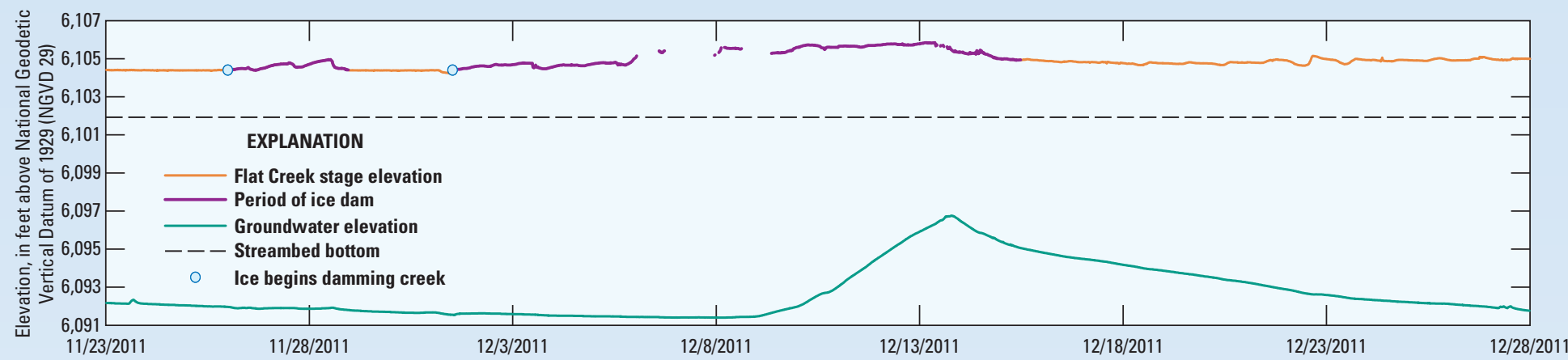

Figure 6. Elevations of Flat Creek below Cache Creek, near Jackson, Wyoming, creek stage, and groundwater level in nearby monitoring well.

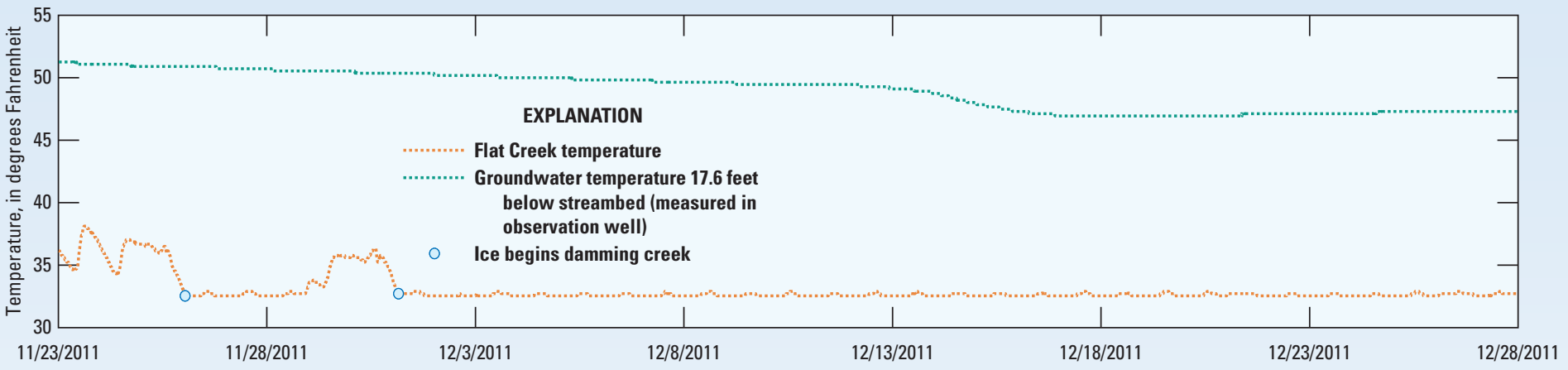

Figure 7. Water temperature of Flat Creek below Cache Creek, near Jackson, Wyoming, and groundwater in the nearby monitoring well. 
Big Sunflower River at Clarksdale, Mississippi (streamgage 07288000)

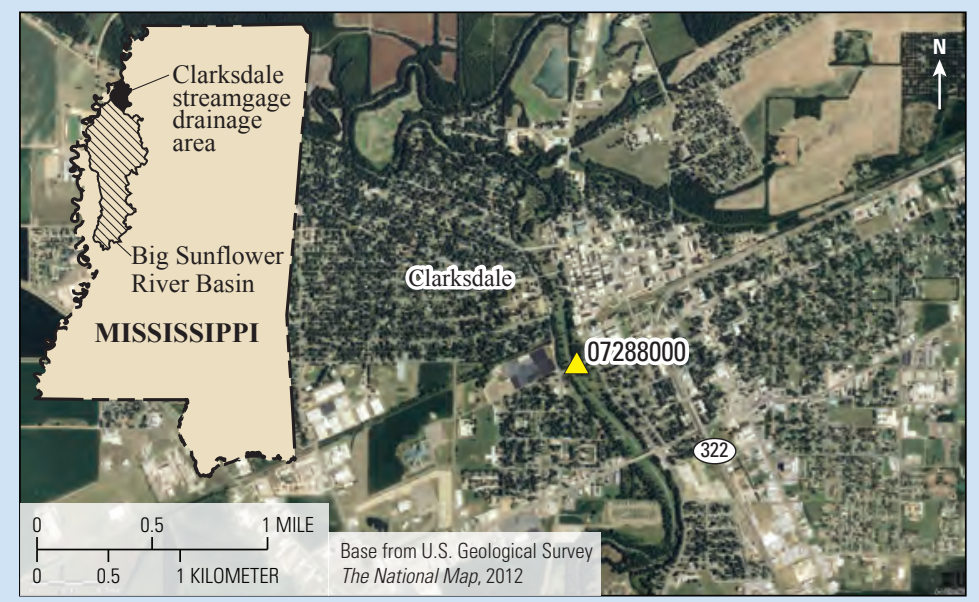

Figure 8. Location of U.S. Geological Survey streamgage 07288000 at the Big Sunflower River at Clarksdale, Mississippi.

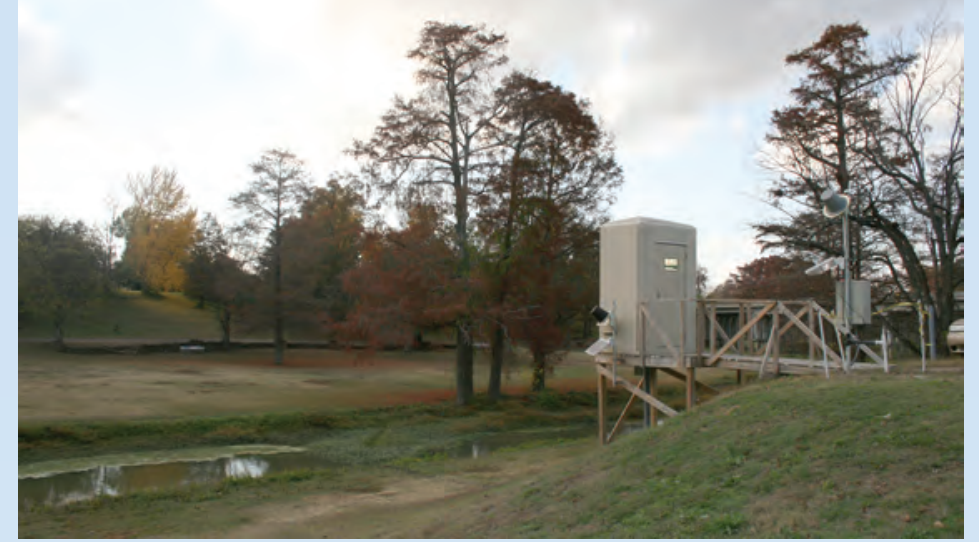

Setting.-The Big Sunflower River (figs. 8 and 9) is located within northwestern Mississippi. The drainage for streamgage 07288000 previously was a flood plain to the Mississippi River and is dominated by irrigated agricultural land use. The observation well is 10 feet from the Big Sunflower River at the USGS streamgage. The well is completed 6 feet below the streambed in silt and fine sand.

\section{Big Sunflower River at Clarksdale, Mississippi.-The} streamgage represents a 108-square-mile drainage area with a mean annual streamflow of 166 cubic feet per second (water years 2009-2011; U.S. Geological Survey, 2011).

Data. - The Big Sunflower River at Clarksdale, Mississippi, is located near the headwaters of the Big Sunflower River and is in connection with the water table of the underlying aquifer. Water-level and temperature data (U.S. Geological Survey, 2011) indicate that the stream is gaining throughout most of the period of record (figs. 10 and 11). The groundwater temperature varies seasonally and is not affected by the stream temperature (fig. 11). Additionally, the installation of a weir in July 2011 is indicated by an increase in the stream stage (fig. 10).

Practical applications. - Data from this site show that even in river systems where the stream is almost always gaining, the relation between the groundwater level and river stage is dynamic, and changes in a river system can potentially affect the groundwater levels.

Figure 9. Big Sunflower River at Clarksdale, Mississippi, on November 24, 2010.

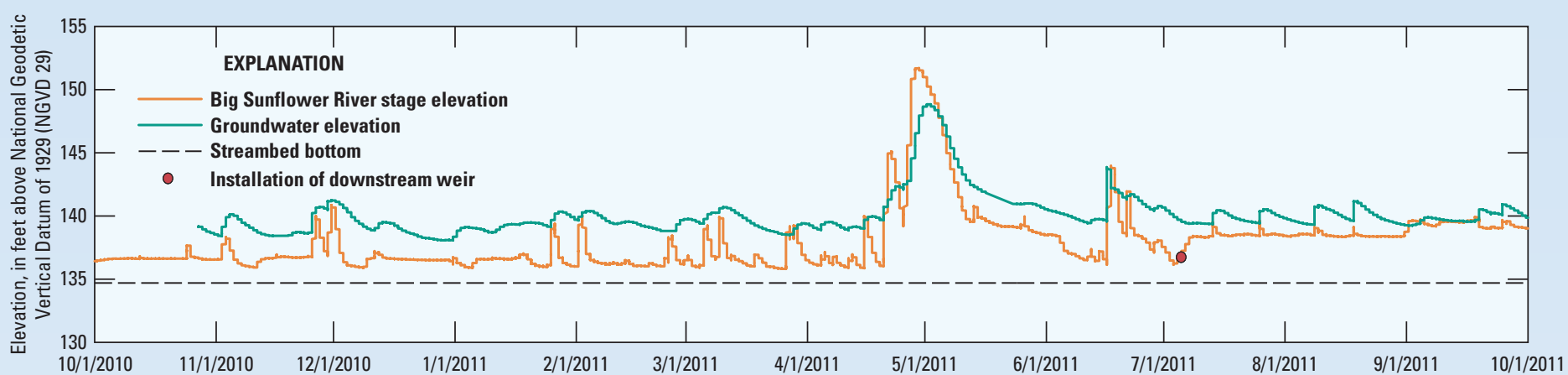

Figure 10. Elevation of Big Sunflower River at Clarksdale, Mississippi, river stage, and groundwater level in nearby monitoring well.

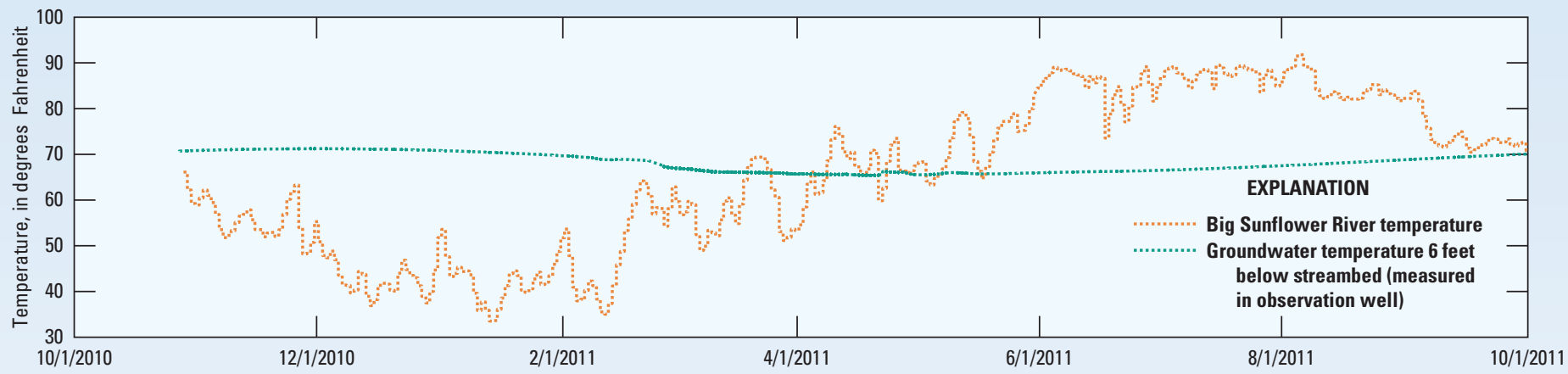

Figure 11. Water temperature of Big Sunflower River at Clarksdale, Mississippi, and groundwater in nearby monitoring well. 
Big Hole River near Melrose, Montana (streamgage 06025500)

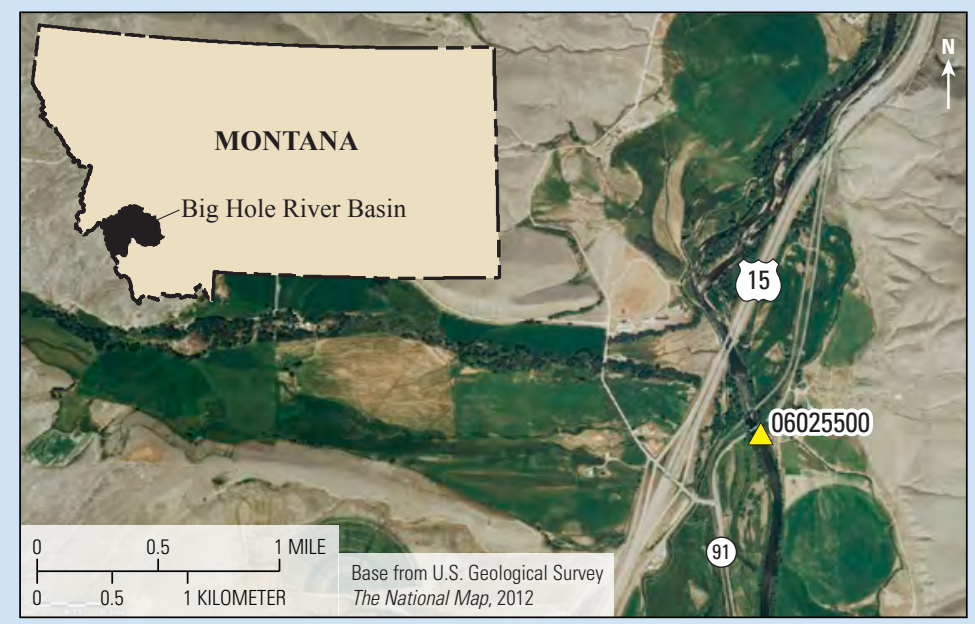

Figure 12. Location of U.S. Geological Survey streamgage 06025500 at the Big Hole River near Melrose, Montana.

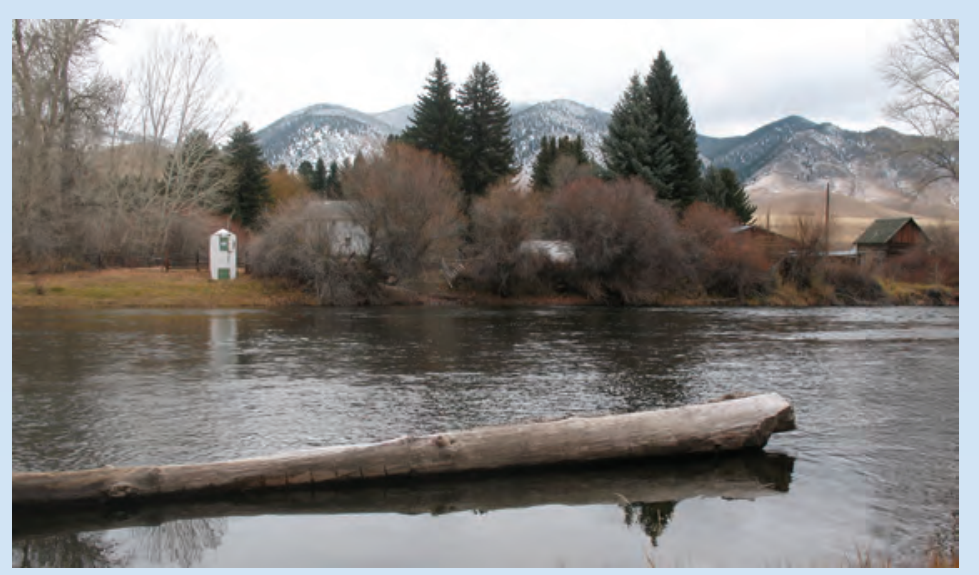

Setting. - The Big Hole River Basin is an intermontane basin in southwestern Montana with grassland and irrigated agriculture in the valleys surrounded by mountains consisting of rangeland and coniferous forests (figs. 12 and 13). The observation well is 30 feet from the Big Hole River at the USGS streamgage. The well is completed 8.5 feet below the streambed in sand and gravel.

Big Hole River near Melrose, Montana.-The streamgage represents a 2,476-square-mile drainage area with a mean annual streamflow of 1,105 cubic feet per second (water years 1924-2011; U.S. Geological Survey, 2011).

Data.-Groundwater levels (U.S. Geological Survey, 2011) followed the general trend of the stream stage during most of the year (for example, April 1, 2010, through September 30, 2010; fig. 14). Groundwater levels noticeably deviated from the stream stage during a period of local canal operation and the flood irrigation of a nearby pasture (fig. 15). Stream temperatures showed diel fluctuations and varied as much as 32 degrees Fahrenheit annually (fig. 15). Groundwater temperature at the bottom of the well lacked diel fluctuation, followed a dampened trend of the stream, and varied about 9 degrees annually (fig 14). The groundwater temperature and water-level data may indicate minimal leakage from the stream to groundwater because water-level gradients were small and dynamic changes in temperature below the streambed were not observed. However, the seasonal change in groundwater temperature may indicate local recharge to the groundwater system through irrigation practices.

Practical applications.-Data from this type of site can be used by water-resource managers in agricultural settings where irrigation practices and the hydrologic response to groundwater and surface-water systems is of interest.

Figure 13. Big Hole River near Melrose, Montana, on November 10, 2010.

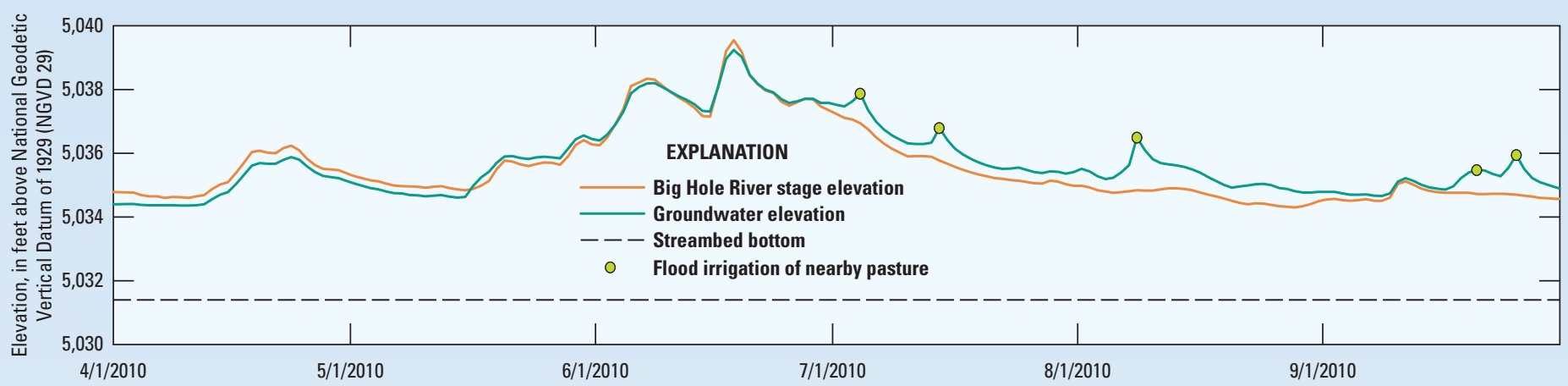

Figure 14. Elevation of Big Hole River near Melrose, Montana, river stage, and groundwater level in the nearby monitoring well.

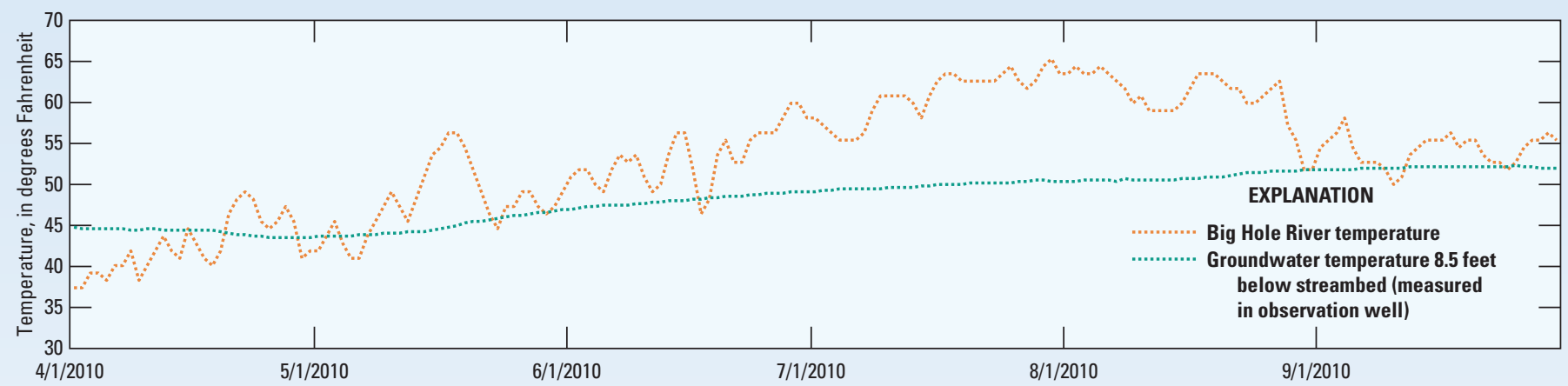

Figure 15. Water temperature of the Big Hole River near Melrose, Montana, and groundwater in the nearby monitoring well. 


\section{What Value Does Real-Time Groundwater Monitoring Add to Streamgages?}

This pilot study showed that coupled real-time monitoring of groundwater and surface water at streambank observation wells and streamgages can substantially enhance the information gained from a streamgage alone. The costs of the additional data collection, quality assurance, transmission of data, and additional maintenance incurred to collect the groundwater levels and the stream and groundwater temperatures added about 5 percent more to the cost of an established, year-round streamgage. Data from the coupled real-time observation wells and streamgages have been shown to be useful for:

- Determining the effects of irrigation practices on local groundwater levels.

- Early warning of flooding from rapidly rising groundwater caused by infiltration from a stream.

- Determining an estimate of stream stage at sites where streamgages are damaged by floods.

- Understanding the groundwater/surface-water interactions and how changes to any part of the system, such as a weir installation, affect the dynamics of the interaction.

These types of data could be collected at selected streamgages across the United States and could be used for a variety of purposes, such as:

- Understanding the effects of groundwater/surface-water exchange on fisheries and other aquatic populations.

- Managing irrigation practices to minimize changes on instream flows to reduce potential effects on endangered species.

- Estimating water fluxes across the streambed by using waterlevel and temperature-based simulations.

- Real-time modeling of chemical fluxes moving between the groundwater and streams.

- Pairing with existing groundwater wells in a watershed to understand ecosystem dynamics and water exchange.

In summary, the pilot study has demonstrated that real-time groundwater monitoring at active streamgages is capable of rapidly providing a suite of four fundamental water characteristics - stream stage, groundwater level, surface-water temperature, and groundwater temperature - as combined resource tools available to the public, ranging from farmers to fisherman to teachers to water-resource managers, with only minor additional costs to existing real-time streamgages.

\section{References Cited}

Alley, W.M., Reilly, T.E., and Franke, O.L., 1999, Sustainability of ground-water resources: U.S. Geological Survey Circular 1186,79 p. (Also available online at http://pubs.usgs.gov/ circ/circ1186/.)

Barlow, J.R.B., and Clark, B.R., 2011, Simulation of water-use conservation scenarios for the Mississippi Delta using an existing regional groundwater flow model: U.S. Geological Survey Scientific Investigations Report 2011-5019, 14 p. (Also available online at $h t t p: / / p u b s . u s g s . g o v / f s / f s-090-01 /$.

Cunningham, W.L., 2001, Real-time ground-water data for the Nation: U.S. Geological Survey Fact Sheet 090-01, 2 p. (Also available online at $h t t p: / / p u b s . u s g s . g o v / f s / f s-090-01 /$.)

Cunningham, W.L., and Schalk, C.W., compilers, 2011, Groundwater technical procedures of the U.S. Geological Survey: U.S. Geological Survey Techniques and Methods, book 1, chap. A1, 151 p. (Also available online at http://pubs. usgs.gov/tm/1a1/.)

Gohn, K.K., compiler, 2004, Celebrating 125 years of the U.S. Geological Survey: U.S. Geological Survey 1274, 56 p. (Also available online at http://pubs.usgs.gov/circ/2004/1274/.)

Nielsen, J.P., and Norris, J.M., 2007, From the river to youUSGS real-time streamflow information: U.S. Geological Survey Fact Sheet 2007-3043, 4 p. (Also available online at http://pubs.usgs.gov/fs/2007/3043/.)

Sauer, V.B., and Turnipseed, D.P., 2010, Stage measurement at gaging stations: U.S. Geological Survey Techniques and Methods, book 3, chap. A7, 45 p. (Also available online at http://pubs.usgs.gov/tm/tm3-a7/.)

Stonestrom, D.A., and Constantz, Jim, 2004, Using temperature to study stream-ground water exchanges: U.S. Geological Survey Fact Sheet 2004-3010, 4 p. (Also available online at http://pubs.usgs.gov/fs/2004/3010/.)

U.S. Geological Survey, 2011, National Water Information System, accessed December 15, 2011, at http://nwis.waterdata. usgs.gov/nwis.

U.S. Geological Survey, 2012, USGS WaterAlert, accessed January 9, 2012, at http://water.usgs.gov/wateralert/.

Wagner, R.J., Boulger, R.W., Jr., Oblinger, C.J., and Smith, B.A., 2006, Guidelines and standard procedures for continuous water-quality monitors - Station operation, record computation, and data reporting: U.S. Geological Survey Techniques and Methods, book 1, chap. D3, 51 p. (Also available online at $h t t p: / / p u b s . u s g s . g o v / t m / 2006 / t m 1 D 3 /$.)

Winter, T.C., Harvey, J.W., Franke, O.L., and Alley, W.M., 1998, Ground water and surface water-A single resource: U.S. Geological Survey Circular 1139, 79 p. (Also available online at http://pubs.usgs.gov/circ/circ1139/.)
By Cheryl A. Eddy-Miller, Jim Constantz, Jerrod D. Wheeler, Rodney R. Caldwell, and Jeannie R.B. Barlow

\section{For more information:}

http://wy.water.usgs.gov/projects/ogw 